\title{
Development of Producer Gas Engines
}

\author{
G Sridhar*, H V Sridhar, S Dasappa, PJ Paul, N K S Rajan and H S Mukunda \\ Combustion Gasification and Propulsion Laboratory \\ Department of Aerospace Engineering \\ Indian Institute of Science \\ Bangalore, India. \\ *corresponding author: gsridhar@cgpl.iisc.ernet.in
}

\begin{abstract}
This paper summarizes the findings involved in the development of producer gas fuelled reciprocating engines over a time frame of six years. The high octane rating, ultra clean and low energy density producer gas derived from biomass has been examined. Development efforts are aimed at a fundamental level, wherein the parametric effects of compression ratio and ignition timing on the power output are studied. These findings are subsequently applied in the adaptation of commercially available gas engines at two different power levels and make. Design of a producer gas carburetor also formed a part of this developmental activity. The successful operations with producer gas fuel has opened possibilities for adapting commercially available gas engine for large scale power generation application, albeit loss of power to an extent of $20-30 \%$. This loss in power is compensated to a much larger proportion by the way of reduction in toxic emissions; these technologies generate fewer amounts of toxic gases (low NOx and almost zero SOx) and zero towards GHG.
\end{abstract}

Keywords: Gas Engine, Producer Gas, Biomass, Compression Ratio, Ignition Timing.

\section{Notations}

$\begin{array}{ll}\text { ABC } & \text { After Bottom Centre } \\ \text { ATC } & \text { After Top Centre } \\ \text { BBC } & \text { Before Bottom Centre } \\ \text { BC } & \text { Bottom Centre } \\ \text { BP } & \text { Brake Power } \\ \text { bsfC } & \text { Brake Specific Fuel Consumption } \\ \text { BTC } & \text { Before Top Centre } \\ \text { CA } & \text { Crank Angle } \\ \text { CFR } & \text { Co-operative Fuel Research } \\ \text { CGPL } & \text { Combustion Gasification and Propulsion Laboratory } \\ \text { CI } & \text { Compression Ignition } \\ \text { COV } & \text { Coefficient of Variation } \\ \text { CPCB } & \text { Central Pollution Control Board } \\ \text { CR } & \text { Compression Ratio } \\ \text { GHG } & \text { Green House Gas } \\ \text { IGN } & \text { Ignition Timing } \\ \text { IISC } & \text { Indian Institute of Science } \\ \text { IMEP } & \text { Indicated Mean Effective Pressure } \\ \text { INJ } & \text { Injection Timing } \\ \text { IP } & \text { Indicated Power } \\ \text { LCV } & \text { Lower Calorific Value } \\ \text { MBT } & \text { Minimum advance for Best Torque } \\ \text { NG } & \text { Natural Gas }\end{array}$




$\begin{array}{ll}\text { PG } & \text { Producer Gas } \\ \text { P-V } & \text { Pressure-Volume } \\ \text { P- } \theta & \text { Pressure-Crank Angle } \\ \text { RG } & \text { Recycled Gas } \\ \text { SI } & \text { Spark Ignition } \\ \text { S }_{\text {L }} & \text { Laminar burning velocity } \\ \text { SERI } & \text { Solar Energy Research Institute } \\ \text { TC } & \text { Top Centre } \\ \Phi & \text { Fuel-air Equivalence ratio }\end{array}$

\subsection{Introduction}

In the recent times, gaseous fuels are gaining prominence as cleaner fuels for power generation via internal combustion engine route; the power generation package including both reciprocating engines and gas turbine machinery. Complete combustion with minimal emission is the key feature of gaseous fuels and this feature is currently being exploited the world-over for power generation purposes. Among the clean sources of fuel for power generation, natural gas has been exploited largely due to significant availability in specific locations. Similarly, there is also an impetus on using gas generated from industrial and municipal wastes, namely diluted natural gas - biogas and land-fill gas. As distinct from gas generation from biological/organic wastes by biological conversion process, which is limited to non-lignaceous matter, the thermochemical conversion route (also termed gasification) can process any solid organic matter. The range of biomass includes agro-residues like rice husk, sugarcane trash and bagasse in compact or briquetted form. The resultant gas known as 'Producer gas' can be used for fuelling a compression ignition $(\mathrm{Cl})$ engine in dual-fuel mode or a sparkignition ( $\mathrm{SI}$ ) engine in gas alone mode. Harnessing of energy from biomass via gasification route is not only proving to be economical but also environmentally benign [1]. In fact, renewable energy is gaining popularity in Europe and the West, referred commonly as the 'Green Energy' and its harnessing is encouraged through attractive incentives on the tariff by the governments.

The technology of biomass gasification has existed for more than seventy years. Some of the work done during World War II is well documented in SERI [2]. Subsequent to World War II, the technology did not gain popularity on two counts, the first reason being unrestricted availability of petroleum fuels the world over at a low cost. The other reason being technological problems relating to the presence of high level of tar content in the product gas, which posed a threat to engine operations. Though there has been a sporadic interest in biomass gasifiers whenever an oil crisis, sustained global interest was developed only in the recent times for reasons like Green House Gas (GHG) emission reduction and carbon-trading through clean development mechanisms. In addition, a steep rise in the oil prices has had a severe impact on the industrial economy and this has forced many oil-importing countries to reconsider gasification technology and initiate improvements in them. The technology of open top, twin air entry, re-burn gasifier developed at Combustion, Gasification and Propulsion Laboratory (CGPL) of Indian Institute of Science (IISC) is unique in terms of generating superior quality producer gas [3].

The work that is reported in this paper is the cumulative effort of six years in realizing of a producer gas engine. During this period, engines of power level between 20 to $200 \mathrm{~kW}$ have been evaluated with the producer gas fuel. This development work involving systematic and scientific investigation was necessary in order to erase some of the misconceptions associated with the low energy density and potential gaseous fuel. 


\subsection{Background}

This development work was initiated in the backdrop of limited information and modest work reported in the field of producer gas engines. Literature survey in the field of producer gas based engines reveals modest research work accomplished since the inception of biomass/charcoal gasification systems. This could be attributed to two reasons, namely nonavailability of standard gasification system that could generate consistent quality producer gas and the other relating to misconceptions about producer gas fuel. The misconceptions are essentially related to compression ratio limitation due to knock and de-rating. The knock tendency with producer gas can be expected to be better on account of large fraction of inert gas it contains as compared to natural gas. However, there has not been any research octane rating test conducted on producer gas fuel and moreover it is not clear if any established test procedure exists for producer gas like the Methane number test for natural gas and biogas. One crude way of assessment is to test the fuel gas in standard engines and place them accordingly in the octane rating table. De-rating using producer gas could be expected on account of reduction in the mixture energy density and the product-to-reactant mole ratio. These issues are addressed in the next section, which discusses the properties of producer gas vis-à-vis other gaseous fuels. The literature survey addresses some of research activities conducted in Europe, America and the Indian sub-continent.

It is reported that Europe exploited the most of gasification technology during petroleum oil crisis of World War II. Among the European nations, Sweden accounts for a large amount of work in the area of wood and charcoal gasification. National Swedish Testing Institute of Agricultural Machinery, Sweden [4] has reported extensive work on the design and development of closed top charcoal and wood gasifiers for use with the reciprocating engines. These reciprocating engines were mostly diesel engines mounted on trucks and tractors for operation in dual-fuel mode. Many finer aspects relating to dual-fuel operation have been extensively reported, with cumulative operational experience exceeding a few thousand hours. However, whatever work was conducted on the producer gas alone operation is either proprietary to the engine manufacturers or is not adequately reported in the public domain literature. These engines were however in the lower CR - 10 either adapted from petrol engines or modified diesel engine. In the recent times, Martin et al [5] have reported work using charcoal gas and biomass based producer gas on a SI engine with a de-rating of $50 \%$ and $40 \%$ respectively at a CR of 7 . However, the same authors state $20 \%$ de-rating when worked with producer gas at a CR of 11. They indicate an upper limit of CR of 14 and 11 for charcoal and biomass based producer gas respectively. However, there is no presentation of experimental evidence in favour of these results.

American sub-continent also claims experimental work relating to producer gas engines. Tatom et al [6] have reported working on a gasoline truck engine with a simulated pyrolysis gas at a de-rating of $60-65 \%$. The authors have also identified the optimum ignition timings as a function of speed. Parke et al $[7,8]$ have worked on both naturally aspirated and super charged gas engines. The authors state a de-rating of $34 \%$, compared to gasoline operation and a lesser de-rating in a supercharged mode. The authors discuss aspects relating to fuel-air mixture ratio, flame speed and its relation to the ignition timing for producer gas operation. They have also identified the best possible mixture for maximum power and efficiency along with ignition timing at various speeds.

In the Indian sub-continent, work in the area of producer gas engine has been reported by Indian Institute of Technology, Mumbai. Shashikantha et al $[9,10]$ and Parikh et al [11] have reported work on a gas engine converted from a naturally aspirated diesel engine at CR of 11.5. The reason for limiting the CR is cited to be the knocking tendency; however, no experimental evidence is provided in support of it. The work is reported on a gas engine converted from a diesel engine with a modified combustion chamber. The modified combustion chamber of Hesselman (shallow W) shape is stated to enhance the in-cylinder turbulence by suppression of 
swirl and promotion of squish effect. With the above modification, a power output of $16 \mathrm{~kW}$ is reported in gas mode against a rated output of $17 \mathrm{~kW}$ in diesel mode. The maximum thermal efficiency is stated at $32 \%$, which is close to the results in compression ignition (with diesel) mode at an output of $15 \mathrm{~kW}$. It is quite surprising to note the conversion efficiencies to be same, when the CRs are widely different. The authors also state an optimum ignition timing of $35^{\circ}$ BTC compared to $22^{\circ}$ BTC for natural gas on the same engine. With the producer gas stating to contain about $24.1 \% \mathrm{H}_{2}, 21.5 \% \mathrm{CO}$ and $2.1 \% \mathrm{CH}_{4}$ the burning velocities ought to be higher than natural gas. This therefore requires the ignition timing to be located close to TC as against what has been stated.

The only earlier experimental work in the higher CR range is reported by Ramachandra [12] on a single cylinder diesel engine $(C R=16.5)$ coupled to a water pump. A power de-rating of $20 \%$ was reported at an overall efficiency of $19 \%$ without any signs of detonation. This work does not report of detailed measurements like the gas composition, pressure-crank angle diagram and emissions, which are essential for systematic investigation and scientific understanding.

If one were to summarize the findings of earlier studies, it becomes evident that no systematic investigation has been attempted so far in identifying if limitation of knock exists with producer gas operation at CR comparable with the diesel engine operation. This topic is worth analyzing since producer gas contains a large fraction of inert (> 50\%) and with laminar burning velocity being high (due to the presence of $\mathrm{H}_{2}$ ), smooth operation at higher $\mathrm{CR}$ does not seem impossible. These aspects are very vital in establishing the fact that close to comparable power (with a lesser extent of de-rating 15-20\%) could be achieved with producer gas by operating in engines at higher $C R$.

\subsection{Producer Gas Fuel}

Producer gas derived from biomass, typically contains $18-20 \%$ each of $\mathrm{H}_{2}$ and $\mathrm{CO}, 2 \% \mathrm{CH}_{4}$ and, rest inert like $\mathrm{CO}_{2}$ and $\mathrm{N}_{2}$. The lower calorific value varies between $4.5-4.9 \mathrm{MJ} / \mathrm{kg}$, with stoichiometric air-to-fuel ratio being $1.25+0.05$ on mass basis. Some of the fundamental data relating to producer gas are compared with pure gases in Table -1. The comparison of producer gas with methane is more vital with regard to the internal combustion engine operation. This is because most of the engines operating on gaseous fuels are either close to pure methane (natural gas) or diluted methane (bio-gas, land-fill gas). The fuel-air equivalence ratio (actual fuel to air ratio)/(stoichiometric fuel to air ratio) at the flammability limits [13] compares closely for both the gases, but the laminar burning velocity for producer gas at the lean limits is much higher. The laminar burning velocity for producer gas (at $0.1 \mathrm{MPa}, 300 \mathrm{~K}$ ) is about 0.5 $\mathrm{m} / \mathrm{sec}$ [13], which is about $30 \%$ higher than methane. This feature is argued to demand lower advancement in the ignition timing and needs consideration while arriving at the optimum ignition timing for the producer gas fuel.

Like any other gaseous fuel, producer gas can be used for internal combustion engine operation provided the gas is sufficiently clean such that contaminant does not accumulate in the intermediary passages to the engine cylinder. But this fuel has largely been left unexploited due to additional perceptions, namely (1) auto-ignition tendency at higher CR, (2) large derating in power due to energy density being low. However, these perceptions need reexamination and clarification. The arguments against the classical view in favour of better knock resistivity are as follows. Firstly, with the laminar burning velocity being high due to the presence of hydrogen (more so, with the gasifier system adopted in this work) might reduce the tendency for the knock. Secondly, the presence of inert in the raw gas $\left(\mathrm{CO}_{2}\right.$ and $\left.\mathrm{N}_{2}\right)$ might suppress the pre-flame reactions that are responsible for knocking on account of increased dilution. Also the maximum flame temperature attainable with the producer gas being lower compared to conventional fuels like methane, one could expect better knock resistivity. An examination of literature shows that producer gas has not been subjected to study on knock behaviour. 
Further, there is a general perception that producer gas being a low-density energy fuel, the extent of de-rating in power would be large when compared to high energy density fuels like natural gas and Liquefied petroleum gas. This could be misleading because what needs to be accounted for comparison is the mixture energy density [14] and not the fuel energy density per se. On comparison with $\mathrm{CH}_{4}$, the mixture energy density for producer gas is lower by $23 \%$ as reflected in Table 1 . The product to reactant mole ratio for producer gas is less than one. These two parameters could contribute to de-rating of engine output. However, it might be possible to reduce de-rating by working with engines of higher $C R$, perhaps higher than what has been examined using natural gas $(C R=15.8)$ by Das et al $[15]$.

Table 1: Properties of Producer Gas (PG) Compared with Pure Combustible Gases

\begin{tabular}{|c|c|c|c|c|c|c|c|c|c|c|}
\hline \multirow{2}{*}{$\begin{array}{c}\text { Fuel } \\
+ \\
\text { Air }\end{array}$} & \multirow{2}{*}{$\begin{array}{c}\text { Fuel LCV, } \\
\mathrm{MJ} / \mathrm{kg} \\
(\mathrm{MJ} / \mathrm{Nm} 3)\end{array}$} & \multirow{2}{*}{$\begin{array}{c}\text { Air/ } \\
\text { Fuel } \\
@ \Phi=1 \\
\text { mass } \\
\text { (mole) }\end{array}$} & \multirow{2}{*}{$\begin{array}{c}\text { Mixture, } \\
\mathrm{MJ} / \mathrm{kg} \\
(\mathrm{MJ} / \mathrm{Nm} 3)\end{array}$} & \multicolumn{2}{|c|}{$\Phi$, Limit } & \multicolumn{2}{|c|}{$\begin{array}{l}\text { SL (Limit), } \\
\mathrm{cm} / \mathrm{s}\end{array}$} & \multirow{2}{*}{$\begin{array}{c}\mathrm{SL} \\
\Phi \\
=1, \\
\mathrm{~cm} / \mathrm{s}\end{array}$} & \multirow{2}{*}{$\begin{array}{c}\text { Peak } \\
\text { Flame } \\
\text { Temp, } \\
\text { K }\end{array}$} & \multirow{2}{*}{$\begin{array}{c}\text { Product/ } \\
\text { Reactant Mole } \\
\text { Ratio }\end{array}$} \\
\hline & & & & Lean & Rich & Lean & Rich & & & \\
\hline $\mathrm{H}_{2}$ & $\begin{array}{c}121 \\
(10.8)\end{array}$ & $\begin{array}{c}34.4 \\
(2.38)\end{array}$ & $\begin{array}{l}3.41 \\
(3.2)\end{array}$ & 0.01 & 7.17 & 65 & 75 & 270 & 2400 & 0.67 \\
\hline $\mathrm{CO}$ & $\begin{array}{c}10.2 \\
(12.7)\end{array}$ & $\begin{array}{l}2.46 \\
(2.38)\end{array}$ & $\begin{array}{l}2.92 \\
(3.8)\end{array}$ & 0.34 & 6.80 & 12 & 23 & 45 & 2400 & 0.67 \\
\hline $\mathrm{CH}_{4}$ & $\begin{array}{c}50.2 \\
(35.8)\end{array}$ & $\begin{array}{c}17.2 \\
(9.52)\end{array}$ & $\begin{array}{l}2.76 \\
(3.4)\end{array}$ & 0.54 & 1.69 & 2.5 & 14 & 35 & 2210 & 1.00 \\
\hline $\mathrm{C}_{3} \mathrm{H}_{8}$ & $\begin{array}{c}46.5 \\
(91.3)\end{array}$ & $\begin{array}{c}15.6 \\
(23.8)\end{array}$ & $\begin{array}{l}2.80 \\
(3.7)\end{array}$ & 0.52 & 2.26 & - & - & 44 & 2250 & 1.17 \\
\hline $\mathrm{C}_{4} \mathrm{H}_{10}$ & $\begin{array}{c}45.5 \\
(117.7)\end{array}$ & $\begin{array}{c}15.4 \\
(30.9)\end{array}$ & $\begin{array}{l}2.77 \\
(3.7)\end{array}$ & 0.59 & 2.63 & - & - & 44 & 2250 & 1.20 \\
\hline PG & $\begin{array}{c}5.0 \\
(5.6) \\
\end{array}$ & $\begin{array}{r}1.35 \\
(1.12) \\
\end{array}$ & $\begin{array}{l}2.12 \\
(2.6) \\
\end{array}$ & $\begin{array}{c}0.47 \\
\mathrm{a} \\
\end{array}$ & $\begin{array}{c}1.60 \\
b\end{array}$ & 10.3 & 12 & $\begin{array}{c}50 \\
\mathrm{C}\end{array}$ & $\begin{array}{c}1800 \\
d\end{array}$ & 0.87 \\
\hline
\end{tabular}

PG: $\mathrm{H}_{2}-20 \%, \mathrm{CO}-20 \%, \mathrm{CH}_{4}-2 \%$; a: +0.01 , b: $+0.05, \mathrm{c}:+5.0$, d: +50 ; Source: Lewis et a l [16], Mukunda [17], Kanitkar et al [13]

\subsection{Producer Gas Carburetor}

Designing of gas carburetor for producer gas fuel assumed major propositions as there are no carburetors available for such low energy density gaseous fuels. The carburetors available for other gaseous fuel, namely the natural gas, biogas and landfill gas are unsuitable due to widely different stoichiometric air-to-fuel requirement. The stoichiometric air-to-fuel ratio varies between 10 to 6 (on volume basis) for fuels such as natural gas and bio-gas/land fill gas based on methane content in the gas. However, stoichiometric air-to-fuel ratio for producer gas is about 1.2 to 1.4 (on volume basis) based on the constituents of the gas. The envisaged features in the gas carburetor are

- Ability to maintain the required air-to-fuel ratio $(1.2$ to $1.5: 1)$ with load or throttle Variation

- Smooth operation with minimal pressure loss

- Shut off the fuel in case of engine tripping or shut-down

- On-line provision for air/fuel tuning during testing 
The above-mentioned feature was incorporated in the development of a gas carburetor and is shown in Fig. 1. The carburetor is simple in design and does not have moving components. It has a separate port for air and fuel, where the individual ports could be modified or tuned to achieve the required air-to-fuel ratio. The carburetor is designed to operate in conjunction with the zero-pressure regulator. The combination of pressure regulator and gas carburetor was located between the gasifier and the engine intake system as shown in Fig. 1. The zero pressure regulator ensures a gas pressure (downstream of the pressure regulator) identical to that of air pressure and this is achieved by connecting the air pressure line (down stream of air filter) to the upper chamber of the regulator. This arrangement ensures the regulator to maintain the gas pressure close to that of air pressure $(\sim$ a few $\mathrm{mm}$ below atmospheric pressure) and thereby the set air/fuel ratio irrespective of the total mixture flow rate. Homogeneity of the fuel and air mixture entering the engine was ensured by having a sufficiently long interconnecting ducting along with a few bends (diameter sufficiently large to keep pressure losses to minimum) between the gas carburetor and the turbocharger or the intake manifold.

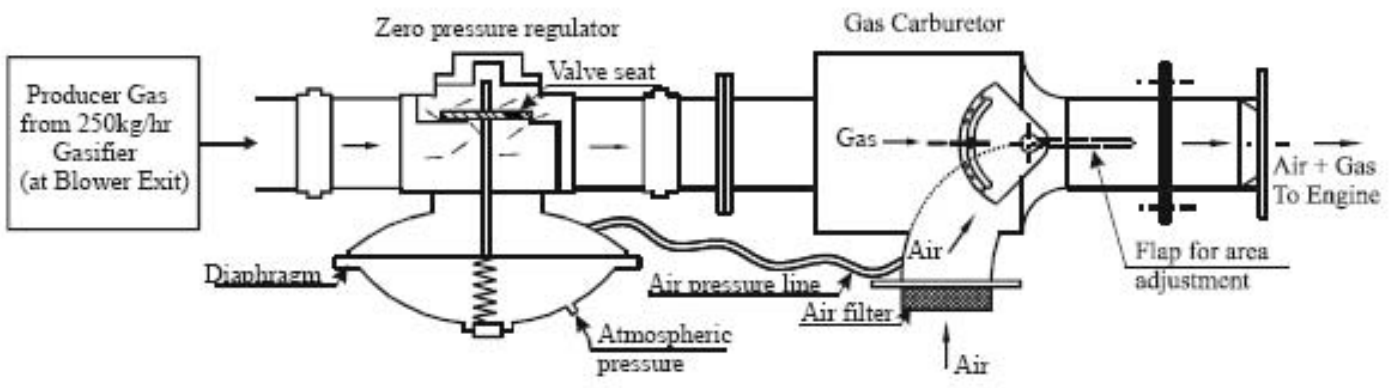

Fig 1 Schematic of Producer Gas Carburetor with Zero Pressure Regulator in the Gas-Air Line Circuit

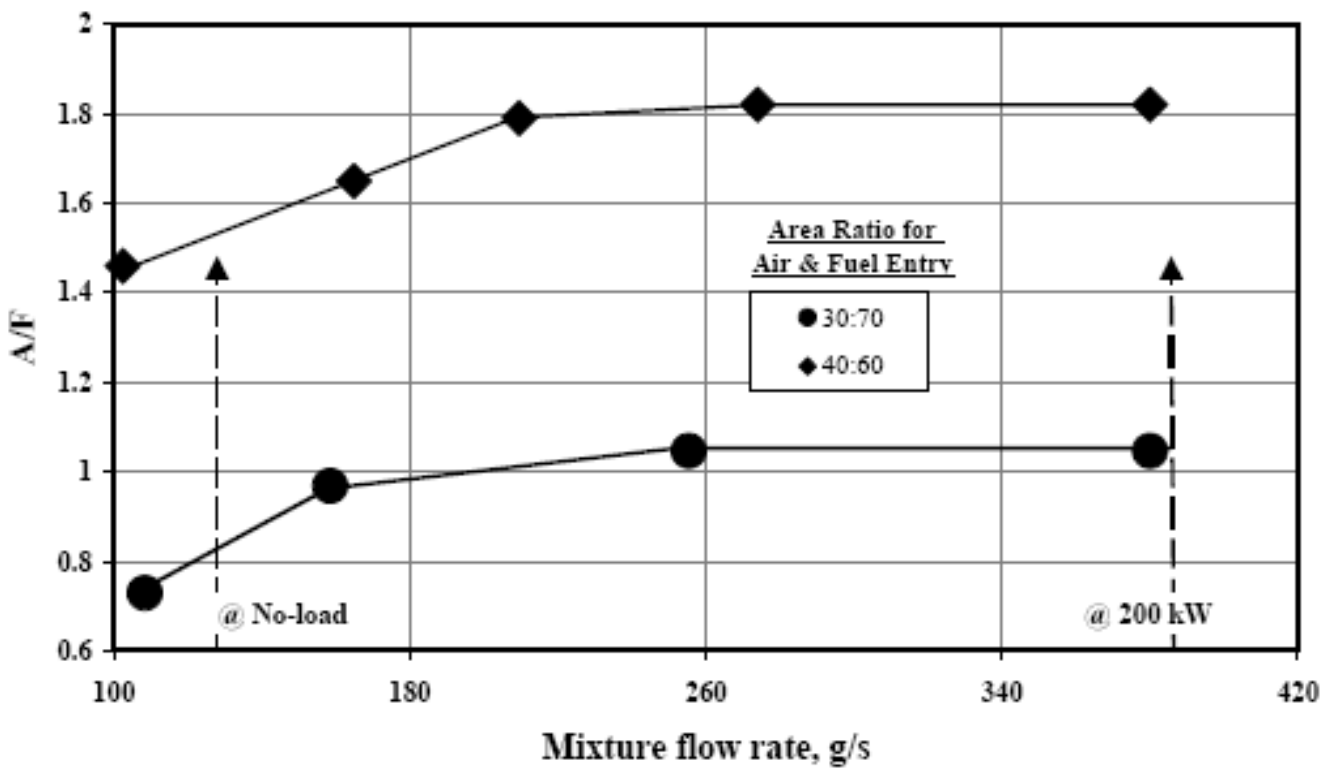

Fig. 2 Flow Tests with Gas Carburetor at Varying Area Ratio for Air and Fuel Entry 
Flow tests performed with zero-pressure regulator and the gas carburetor showed reasonable functioning in terms of air-to-fuel ratio control against total or mixture flow rate variations as shown in Fig. 2. Flow test was conducted using a blower to simulate the engine suction. This simulation should hold good for a multi-cylinder engine where the pulsating flow gets evened out, but possibly not so for a single cylinder engine. The air and fuel flow rates were individually measured over a range of engine's operating conditions. However, the homogeneity of the air and fuel mixture is not addressed here and is expected to be taken up as a separate study considering its importance particularly for naturally aspirated engine. The two cases shown in the above figure correspond to area ratios for the air and fuel entry. These cases are possibly the extreme limits and the required operation point for the engine operation could lie in between them. The A/F ratio was reasonably constant beyond a specified mixture flow rate, with relatively rich mixture at low mixture flow rates. This characteristic is desirable from the viewpoint of engine operation - rich mixture for engine start-up and no-load operations, relatively leaner mixture during part load operation. However, for peak load operation - stoichiometry or rich mixture is desired calling for the adjustment of the carburetor flap. Considering gas engine operation at the field level, the carburetor is designed in such a manner that in the event of load throw-off the flap of the carburetor could move to full air flow (by motorizing) condition thus ensuring safety of the engine.

\subsection{The Experiments}

Three engines of the following configuration as given in Table 2 were tested. These are basically engine-alternator set meant for power generation applications. One of these is a diesel engine (E1), which was converted to a spark-ignition engine at the laboratory. The details of conversion are dealt in the earlier work [18, 19]. Engine E1 was subjected to systematic investigations, wherein the engine was tested at varying compression ratios (CR) of 17, 14.0, 13.5 and 11.5. However, the engines E2 and E3 were tested at the fixed CR as mentioned in the Table. These two engines are essentially factory converted spark ignition engines from the diesel engine frame to operate on gaseous fuels. Load tests were conducted on the engine in order to determine the maximum power delivered. Therefore, the air-to-fuel ratio and the ignition timing were tuned in order to derive maximum output.

Table 2: Engine Specifications

\begin{tabular}{|l|l|l|l|}
\hline Parameter & Engine 1 (E1) & Engine 2 (E2) & Engine 3 (E3) \\
\hline Make and Model & Kirloskar, RB-33 & Greaves, TBDV12 & Cummins, G743G \\
\hline Engine Type & $\begin{array}{l}\text { In-Line, 3 Cylinder, } \\
\text { Naturally Aspirated } \\
\text { Diesel Engine }\end{array}$ & $\begin{array}{l}\text { 'V' Configuration, 12 } \\
\text { Cylinder, Turbo- } \\
\text { Charged with After } \\
\text { Cooler Gas Engine }\end{array}$ & $\begin{array}{l}\text { In-line, 6 cylinder, 4- } \\
\text { stroke, Naturally } \\
\text { Aspirated Gas Engine }\end{array}$ \\
\hline $\begin{array}{l}\text { Rated Output - } \\
\text { 1500 Rev/Min @ } \\
\text { sea level }\end{array}$ & $28 \mathrm{~kW}$, with diesel fuel & $\begin{array}{l}290-310 \mathrm{~kW} \\
\text { (Estimated) Using } \\
\text { Diesel }\end{array}$ & $\begin{array}{l}101 \mathrm{~kW} \text { with natural } \\
\text { gas }\end{array}$ \\
\hline $\begin{array}{l}\text { Net Output* - @ } \\
\text { Bangalore } ~ \\
\begin{array}{l}\text { 1000m above sea } \\
\text { level }\end{array}\end{array}$ & $24 \mathrm{~kW}$, with diesel fuel & $\begin{array}{l}240-258 \mathrm{~kW} \text {, with } \\
\text { diluted natural gas }\end{array}$ & $\begin{array}{l}84 \mathrm{~kW} \text {, with natural } \\
\text { gas }\end{array}$ \\
\hline $\begin{array}{l}\text { Bore } \times \text { Stroke, mm } \\
\text { Total } \\
\text { Displacement, L }\end{array}$ & 3.3 & $\begin{array}{l}128 \times 140 \\
21.6\end{array}$ & $\begin{array}{l}130 \times 152 \\
12.1\end{array}$ \\
\hline $\begin{array}{l}\text { Specific Power, } \\
\text { kW/L }\end{array}$ & 8.5 (with diesel) & $13.4-14.4$ (with diesel) & 7.0 (with NG) \\
\hline $\begin{array}{l}\text { Compression } \\
\text { Ratio (CR) }\end{array}$ & 17 & 12 & 10 \\
\hline
\end{tabular}




\begin{tabular}{|l|l|l|l|}
\hline Parameter & Engine 1 (E1) & Engine 2 (E2) & Engine 3 (E3) \\
\hline $\begin{array}{l}\text { Bumping } \\
\text { Clearance, mm }\end{array}$ & 1.5 & 1.6 & 11 \\
\hline $\begin{array}{l}\text { Combustion } \\
\text { Chamber }\end{array}$ & $\begin{array}{l}\text { Flat Cylinder Head and } \\
\text { Hemispherical Bowl-in } \\
\text { Piston Type }\end{array}$ & $\begin{array}{l}\text { Flat Cylinder Head and } \\
\text { Cylindrical Bowl-in } \\
\text { Piston }\end{array}$ & $\begin{array}{l}\text { Flat cylinder head and } \\
\text { a Shallow Bowl-in } \\
\text { piston type }\end{array}$ \\
\hline Squish Area & $70 \%$ & $68 \%$ & $35 \%$ \\
\hline $\begin{array}{l}\text { Spark Plug Type } \\
\text { \& Location } \\
\text { - Gas Mode }\end{array}$ & $\begin{array}{l}\text { Cold, Offset from the } \\
\text { Axis of Cylinder by } \\
\text { 8mm }\end{array}$ & $\begin{array}{l}\text { Cold, Offset - Located } \\
\text { in the Vertical Plane } \\
\text { Close to the Outer Edge } \\
\text { of the Bowl }\end{array}$ & Central \\
\hline $\begin{array}{l}\text { Conversion/mo- } \\
\text { dification, if any }\end{array}$ & Converted to SI engine & $\begin{array}{l}\text { Producer Gas } \\
\text { Carburetor adapted }\end{array}$ & $\begin{array}{l}\text { Producer Gas } \\
\text { Carburetor adapted }\end{array}$ \\
\hline
\end{tabular}

* Net Output - after deducting power drawn by engine accessory drives

The gas engine was connected to the biomass gasification plant, whose system elements are shown in Fig. 3. Experiments were initiated on the engines only after the gasifier system stabilised i.e. attained steady state operation in terms of generation of consistent quality gas. Typical time scale for attaining steady state of operation from the 16 cold start was 2 to 3 hours. During this period the gas was flared in a burner. The gas composition was determined using on-line gas analysers, pre-calibrated using a known producer gas mixture. The calibrations of these analysers were checked at random time intervals so as to minimise errors in long duration operation. Typically gas composition at the time of start of engine test was 19 $+1 \%-\mathrm{H}_{2} ; 19+1 \%-\mathrm{CO} ; 2 \%-\mathrm{CH}_{4} ; 12+1 \% \mathrm{CO}_{2} ; 2+0.5 \% \mathrm{H}_{2} \mathrm{O}$ and rest, $\mathrm{N}_{2}$. The mean calorific value of gas varied around $4.5+0.2 \mathrm{MJ} / \mathrm{kg}$. The contaminant levels (particulate and tar) in the gas at the entry to the engine were of the order of $60 \mathrm{mg} / \mathrm{Nm}_{3}(\mathrm{ppm})$ in the case of the tests with engine E1, however in the tests with engine E2 and E3, it was as low as $2 \mathrm{ppm}$ and $0.02 \mathrm{ppm}$ respectively. This low level of contaminant was possible by employing a much superior gas scrubbing system during the experiments on engine E2 and E3. The feedstock used for gasification is Causurina species wood and coconut shells with moisture content between 12 to $15 \%$ on dry basis (sun dried wood).

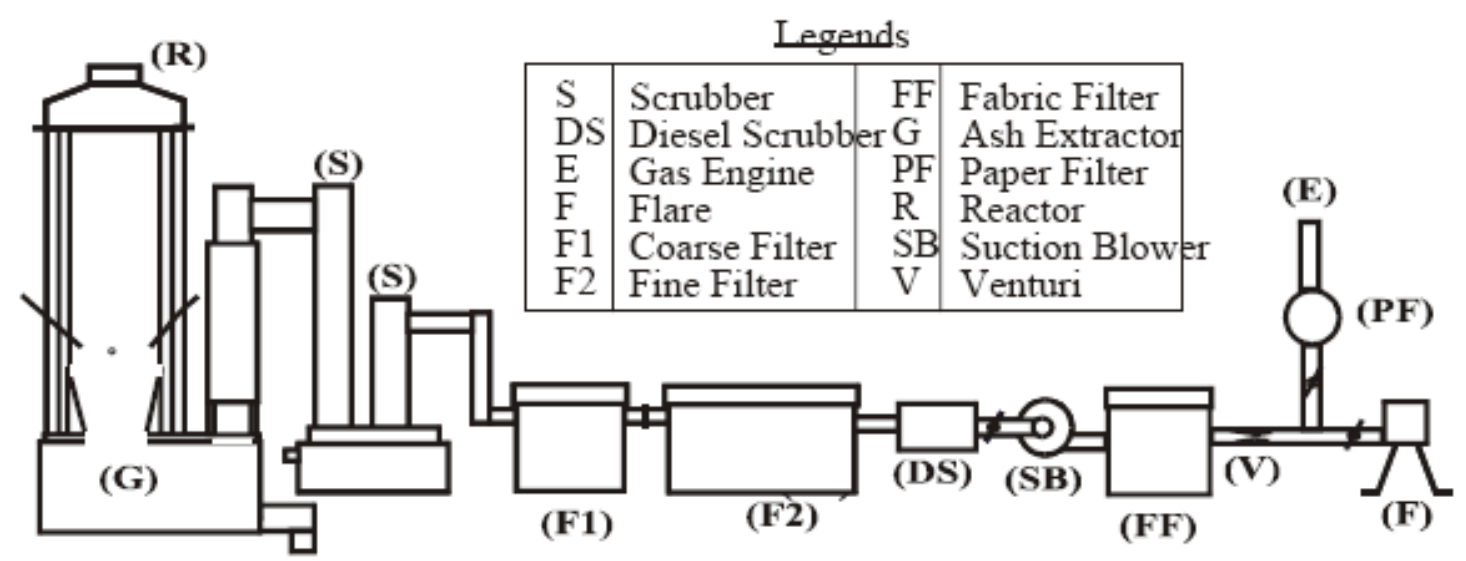

Fig. 3. Schematic of Open Top Re-burn Gasifier Connected to gas engine

All the tests on the engine were conducted around constant speed of $1500+50$ RPM. The throttling for speed control and air and fuel proportioning was achieved using manually operated valves in the case of E1. However, in the case of E2/E3, it was achieved using gas carburettor and electronic/hydraulic governor respectively. The engine E1 was tested at 
varying CRs of 17, 14, 13.5 and 11.5; however, E2 and E3 were tested at CR= 12 and 10 respectively. The engines were tested at different ignition timing settings to determine the optimum ignition timing, referred as MBT (Minimum advancefor Best Torque) at different CRs. Measurements were made with respect to the power output (voltage and current), air and input fuel gas flow and exhaust emissions - CO and NO [18, 19]. Particulate measurement was not envisaged because since the input feed was gas with low particulate matter. For instance in the case of engine $\mathrm{E} 1$, particulate was averaging about $60 \mathrm{mg} / \mathrm{Nm}_{3}$ and this would amount less than $25 \mathrm{mg} / \mathrm{Nm}_{3}$ (some particulate matter would burn) in the exhaust (air-to-fuel gas ratio 1.3). The in-cylinder pressure data with a resolution of one-degree crank angle was acquired on a computer for engines E1 and E2.

\subsection{Performance}

The performance of the three engines in terms of power output, energy balance and emissions are discussed in the following sections in a sequence. The findings obtained from the investigations [18, 19] of engine E1 were used in the adaptation and testing of the engines E2 and E3. Further, the engine E1 was subjected for reliability tests by continuously operating it for 100 hours, similarly the engine E3 was subjected two trials of 24 hours duration (non-stop) each and performance was assessed. The engine operations were found to be satisfactory. Examination of the interior components of the engine - piston and cylinder revealed that combustion to be complete with carbon deposits to much lower extent compared to diesel fuel operations for comparable duration run.

\subsection{Power Output}

Summarizing the performance of the engines, p- $\theta$ was acquired on engine E1 and E2 in order to essentially establish if knock occurs with producer gas operation at varying CRs. Apart from this it was also used for identifying MBT. The outcome of these tests was that the engine E1 worked smoothly without any sign of knock at the CR of 17 and similarly engine E2 at CR= 12 in turbocharger mode. There was no sign of audible knock during the entire load range. Moreover, the absence of knock is clear from the pressure-crank angle $(p-\theta)$, which does not show any pressure oscillations (based on a number of individual cycles), either at part load or at full load (wide open throttle) conditions. The $p$ - $\theta$ diagrams for engine E1 at various CR around optimum ignition timing is shown in Fig. 4, similarly the data at a fixed $C R=12$ for engine $E 2$ is shown in Fig. 5.

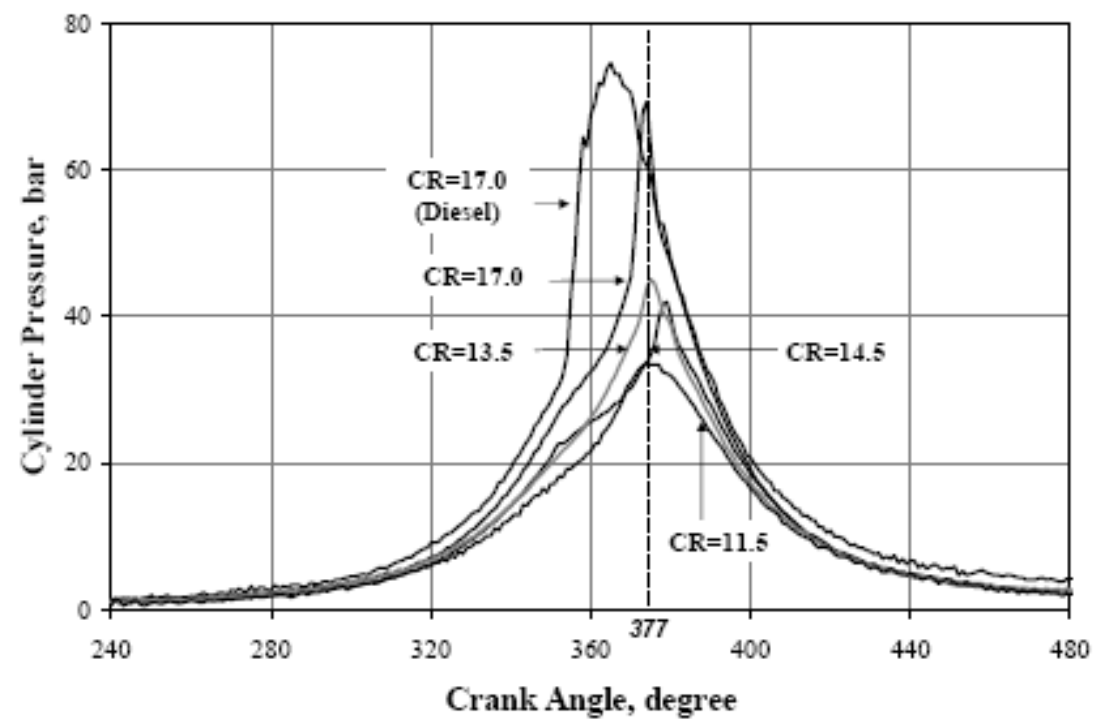

Fig. 4 Comparison of $\mathrm{p}-\theta$ Curves at Different CR; Ignition Timing is at MBT or Close to MBT (Within MBT $+2^{\circ} \mathrm{CA}$ ). The $p-\theta$ curves correspond to ignition setting of $10^{\circ}, 10^{\circ}, 14^{\circ}$ and $15^{\circ}$ BTC for CR of 17, 14.5, 13.5 and 11.5 
respectively. Operation in Diesel Mode at $90 \%$ of rated Load (at Optimum Injection Timing - $34^{\circ}$ BTC). All are Ensemble-Averaged Data Over 30 Consecutive Cycles. The net brake power and $\Phi$ for these cycles are shown in Table 5.

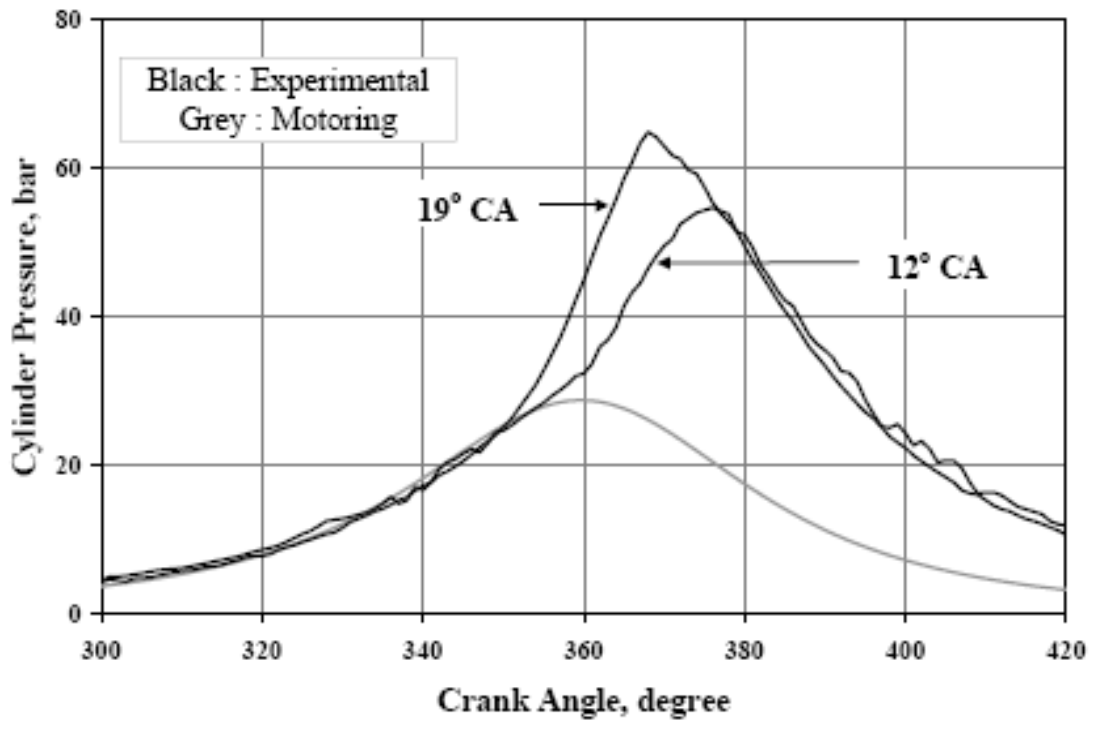

Fig. 5 p- $\theta$ Recording at Varying Ignition Advance at $80 \%$ of the achieved maximum output with Producer Gas. Ensemble- Averaged Data Over 30 Consecutive Cycles

The net work delivered over a complete cycle can be found by integrating the pressure-volume $(\mathrm{p}-\mathrm{v})$ data over the four processes. This also helped in identifying the optimum ignition timing for a given CR - commonly referred as MBT. It is well identified in the literature $[20,21]$ that MBT corresponds to a value wherein the peak cylinder pressure should occur at $16-17^{\circ}$ ATC. The net indicated mean effective pressure (IMEP) obtained from the integrated $p-v$ data is a measure of effectiveness with which an engine of a given volumetric displacement converts the input energy into useful work. The IMEP obtained from ensemble average $p$-v data ( 30 cycles) in the case of engine E1 at varying CR as a function of ignition timing is shown in Figure 6. At $\mathrm{CR}=17$, the maximum IMEP recorded is 5.98 bar corresponding to a ignition timing of $6^{\circ} \mathrm{CA}$ and this declined to 4.85 bar with ignition timing being $15^{\circ} \mathrm{CA}$ at CR of 11.5. These values are obtained at $\Phi=1.08+0.2$ and fall within the anticipated value of $\Phi=1.0$ to 1.1 [20]. It is also evident from the plot that variations in the IMEP values are modest between ignition timings of 6 and $12^{\circ} \mathrm{CA}$ corresponding to $\mathrm{CR}=17$. 


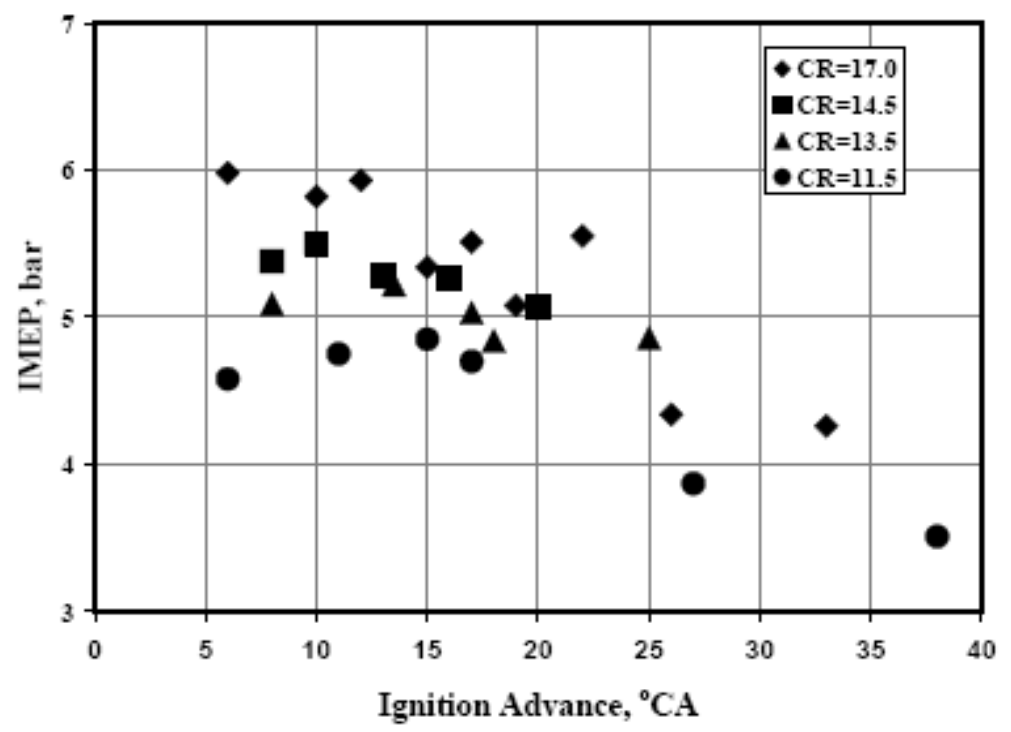

Fig. 6 Variation of IMEP (Net) for engine E1 with Ignition Advance at Various CRs

The coefficient of variation of the IMEP at all CRs and ignition settings occurred well within 3$3.5 \%$, implying low cycle-to-cycle variation. The reason for low cyclic variation is the faster rate of combustion [19, 22] occurring inside the engine cylinder. The faster rate of combustion is attributed to higher flame speeds due to the presence of hydrogen in the gas and also to the combustion chamber design. Exploring further the $p-\theta$ data, the peak pressure and the point of occurrence at ignition timings close to MBT are listed in Table 3 . The measurements made on the engines are accurate within - $1.0^{\circ} \mathrm{CA}$ (due to possible lag in the signal and error in TC identification as mentioned earlier). In the case of engine E1, it is evident from the data that peak pressure seemed to occur between 17 and $19^{\circ}$ ATC (After Top Centre) at all CRs. In the case of $C R=13.5$, the peak pressure seemed to occur at the optimum value $\left(17^{\circ} \mathrm{ATC}\right)$ identified in the literature $[20,21]$. In the case of $C R=11.5$, the peak pressure occurred at 17 and $12^{\circ}$ ATC for an ignition timing of 15 and $17^{\circ}$ BTC respectively. The difference in the IMEP between the two ignition timings was found to be $3 \%$. However, for CR of 17 and 14.5 the ignition timing identified in the able 3 seemed to be marginally deviating from the optimum value. The variation of IMEP within this close range would be marginal as it is well acknowledged that the relative torque delivered has a flatter characteristic around MBT [20]. Similarly the MBT for engine E2 is found to be at $12^{\circ}$ BTC as shown in Table 3. The understanding obtained on MBT from engine $E 1$ and $E 2$ were used in identifying the MBT for the engine E3, since $p-\theta$ data was not acquired for this particular engine.

Table 3: Cylinder Peak Pressures and Their Occurrence Close to MBT

\begin{tabular}{|l|l|l|l|l|}
\hline \multirow{2}{*}{ Engine } & $\mathrm{CR}$ & Ign. advance $^{\circ} \mathrm{CA}$ & Peak pressure, bar & Occurrence $^{\circ}$ ATC \\
\hline \multirow{3}{*}{ E1 } & 17.0 & 6 & 55 & 20 \\
\cline { 2 - 5 } & 14.5 & 10 & 43.3 & 19 \\
\cline { 2 - 5 } & 13.5 & 14 & 45.0 & 17 \\
\cline { 2 - 5 } & 11.5 & 15,17 & $33 ., 38$ & 17,12 \\
\hline E2 & 12.0 & 12 & 55 & 16 \\
\hline
\end{tabular}

Next, the net brake output at varying ignition timing for four different CRs on Engine E1 is shown in Table 4. It is evident from the data that ignition timing had to be retarded with the 
increase in $\mathrm{CR}$ in order to obtain higher output. This is because the thermodynamic conditions in terms of pressures and temperature are more severe at higher $C R$ and thereof the combustion is faster thus calling for the optimum ignition timing to be located close to TC. The maximum output was recorded at an ignition advance of $6^{\circ} \mathrm{BTC}$ at $\mathrm{CR}=17$ and increased to about $15-17^{\circ} \mathrm{BTC}$ at a $\mathrm{CR}=11.5$. At intermediate $\mathrm{CR}$ of 14.5 and 13.5 the ignition advance was 10 and $14^{\circ}$ BTC respectively. The fuel-air equivalence ratio was about $1.06+0.5$ in most of the cases, with efficiency of 30.7 and $27.5 \%$ corresponding to maximum output at higher and lower CRs respectively. An isolated case of efficiency at $31 \%$ was seen corresponding to ignition setting of $12^{\circ} \mathrm{CA}$, probably due to relatively leaner operation. In the above data presented, the air-tofuel ratio was tuned from the viewpoint of deriving maximum output and therefore the efficiency figures are necessarily not the maximum that can be obtained.

Next, the result of the net brake output with three engines at MBT is shown in Table 5. At $\mathrm{CR}=17$, the engine delivered a maximum net brake output of $20 \mathrm{~kW}(17.5 \mathrm{kWe})$ at an efficiency of $30.7 \%$ compared to $24 \mathrm{~kW}(21 \mathrm{kWe}$ ) brake output at 33\% efficiency with diesel (compression ignition mode). The efficiency calculation is based on the ratio of net brake output to the energy content of the air and gas mixture. The useful output and efficiency decreased with the lowering of CR. A maximum net brake output of $17.6 \mathrm{~kW}(15.3 \mathrm{kWe})$ at an efficiency of $27.5 \%$ was obtained at CR of 11.5. The power output at intermediate CR of 14.5 and 13.5 were 18.8 and $18.6 \mathrm{~kW}$ respectively and with efficiencies around $29 \%$. The efficiency at CR $=13.5$ was comparable to that at 14.5 probably due to relatively leaner operation. The extent of de-rating in brake power was about $16.7 \%$ at $C R=17$ and increased to as high as $26 \%$ at $C R=11.5$ compared withbaseline operations in diesel mode.

In the case of engine E2 at a fixed CR of 12 a maximum net brake output of $182 \mathrm{~kW}$ (excluding $12 \mathrm{~kW}$ consumed by the radiator fan) was recorded with an ignition advance between 12 and $14^{\circ} \mathrm{CA}$ at $\Phi=0.94$, against a MBT of $28^{\circ} \mathrm{CA}$ with diluted NG [19]. The value of $\Phi$ was lower in the current case because of limitation coming from the gasification system. In fact, the gas composition in terms of combustibles deteriorated with increased supply of the gas to the engine. This therefore limited the input energy to the engine. The maximum net brake output was obtained at an ignition advance between 12 and $14^{\circ}$ CA with gas-to-shaft efficiency being $28.3 \%$. The point to be noted here is the optimum timing; the maximum power output is obtained at slightly retarded ignition timing as compared to the engine E1 at comparable CR. This could probably be due to faster combustion due to higher turbulence (mean speed of the piston is $7.0 \mathrm{~m} / \mathrm{s}$ against $5.8 \mathrm{~m} / \mathrm{s}$ in E1) and higher cylinder pressure and temperature due to turbocharging. In the case of engine E3, a maximum output of $60 \mathrm{~kW}$ was obtained at an ignition advance of $22-24^{\circ} \mathrm{BTC}$ against an MBT of $35^{\circ} \mathrm{CA}$ with pure NG [23]. The advancement in the ignition timing as compared to E1 and E2 could mostly be related to the combustion chamber design and to some extent due to reduction in CR. 
Table 4: Maximum Net Engine Output on Engine E1 as a Function of Ignition Timing and CR

\begin{tabular}{|c|c|c|c|c|c|c|c|}
\hline $\begin{array}{l}\text { IGN, } \\
\text { BTC }\end{array}$ & $\Phi$ & $\begin{array}{l}\text { BPnet, } \\
\text { kW* }\end{array}$ & $\begin{array}{c}\eta \text { : Gas-to- } \\
\text { Shaft, } \%\end{array}$ & $\begin{array}{l}\text { IGN, } \\
\text { BTC }\end{array}$ & $\Phi$ & $\begin{array}{l}\text { BPnet, } \\
\text { kW* }^{*}\end{array}$ & $\begin{array}{c}\eta \text { : Gas-to- } \\
\text { Shaft, } \%\end{array}$ \\
\hline \multicolumn{4}{|c|}{$C R=17.0$} & \multicolumn{4}{|c|}{$C R=14.5$} \\
\hline 06 & 1.10 & 20.0 & 30.8 & 08 & 1.20 & 18.6 & 25.0 \\
\hline 12 & 1.00 & 19.8 & 31.0 & 10 & 1.10 & 18.8 & 29.0 \\
\hline 17 & 1.09 & 18.4 & 29.0 & 16 & 1.11 & 17.9 & 27.5 \\
\hline 22 & 1.03 & 17.9 & 28.0 & 20 & 1.11 & 17.7 & 27.2 \\
\hline 26 & 1.10 & 16.2 & 25.3 & & & & \\
\hline 33 & 1.25 & 14.0 & 19.0 & & & & \\
\hline \multicolumn{4}{|c|}{$C R=13.5$} & \multicolumn{4}{|c|}{$C R=11.5$} \\
\hline 08 & 1.05 & 18.2 & 28.6 & 06 & 1.07 & 17.0 & 27.0 \\
\hline 14 & 1.06 & 18.6 & 29.0 & 15,17 & 1.07 & 17.6 & 27.5 \\
\hline 18 & 1.07 & 17.0 & 27.8 & 27 & 1.09 & 15.6 & 25.5 \\
\hline 25 & 1.06 & 17.0 & 28.0 & 38 & 1.07 & 13.3 & 20.0 \\
\hline
\end{tabular}

* Excluding Radiator Fan Power

Table 5: Maximum Net Engine Output on Different Engines

\begin{tabular}{|c|c|c|c|c|c|c|c|}
\hline Engine & CR & $\begin{array}{c}\text { IGN, } \\
\text { BTC }\end{array}$ & $\Phi$ & $\begin{array}{c}\text { Net Elec. } \\
\text { Power, kWe }\end{array}$ & $\begin{array}{c}\text { Net Brake } \\
\text { Power } \\
\text { (BPNet) }, \mathrm{kW}\end{array}$ & $\begin{array}{c}\text { Mixture Energy } \\
\text { Density, MJ/kg }\end{array}$ & $\begin{array}{c}\text { Efficiency: } \\
\text { Gas-to- } \\
\text { Shaft, \% }\end{array}$ \\
\hline \multirow{2}{*}{ E1 } & 17.0 & 06 & 1.10 & 17.5 & 20.0 & 2.20 & 30.7 \\
\cline { 2 - 8 } & 14.5 & 10 & 1.10 & 16.4 & 18.8 & 2.20 & 29.0 \\
\cline { 2 - 8 } & 13.5 & 14 & 1.06 & 16.2 & 18.6 & 2.10 & 29.3 \\
\cline { 2 - 8 } & 11.5 & $\begin{array}{c}15, \\
17\end{array}$ & 1.07 & 15.3 & 17.6 & 2.20 & 27.5 \\
\hline \multirow{2}{*}{ E2 } & 12 & $\begin{array}{c}12, \\
14\end{array}$ & 0.94 & 165 & 182 & 1.90 & 28.3 \\
\hline \multirow{2}{*}{ E3 } & 10 & $\begin{array}{c}22, \\
24\end{array}$ & 1.01 & 55 & 60 & 2.15 & 27.4 \\
\hline
\end{tabular}

$\Phi$ =Equivalence Ratio: (Actual fuel- to- air ratio)/ (Stoichiometric fuel- to- air ratio) 


\subsection{Energy Balance}

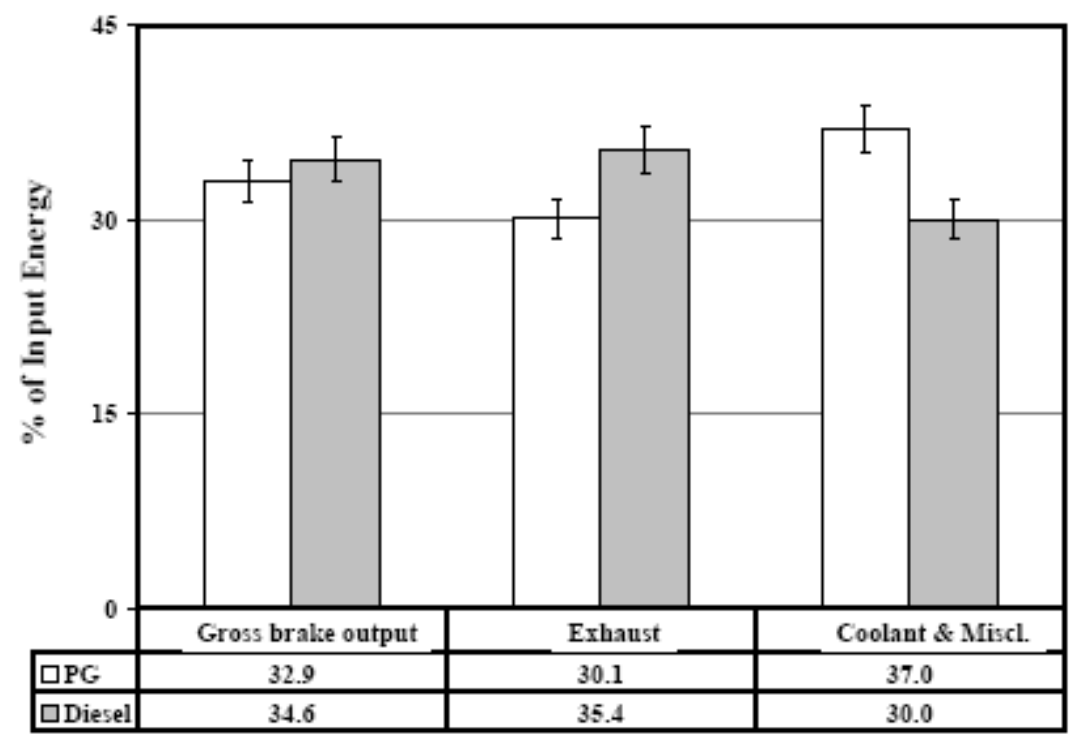

Fig. 7 Energy Balance Comparison for engine E1 in Diesel and Producer Gas Mode at Maximum Brake Output. The Marker Refers to the Error Band.

Figure 7 represents the overall energy balance at $C R=17$. The energy balance is based on gross brake power output. The gross brake output is the sum of net shaft output and power consumed by engine accessories (water pump/fan, dynamo and FIP $=1.4 \mathrm{~kW}$ ). The energy balance in gas mode corresponding to maximum brake output (at $6^{\circ} \mathrm{CA}$ ) showed a useful output (Gross brake power) of $32.9 \%$, about $30 \%$ is lost through exhaust (sensible and chemical enthalpy - CO) and remaining 37\% to the cooling water (inclusive of frictional and radiative losses). Figure 7 also compares the energy balance in gas and diesel mode (at rated output of $24 \mathrm{~kW}$ ) at CR of 17 , the energy loss to the coolant and miscellaneous is about $37 \%$ compared to $30 \%$ in diesel and whereas, energy loss through exhaust is lower by about $5 \%$ in gas mode. Overall the brake thermal efficiency is lower by about $1.5 \%$ in gas. . The energy balance as a function of CR is shown in Figure 8. There is an increase in energy loss through exhaust with the reduction in the $C R$, where as the loss through the coolant is higher at higher CR. The increased amount of heat loss to the cooling water in gas operations is attributed to engine combustion chamber design. Heywood [20] indicates that engine geometries such as bowl-inpiston would experience $10 \%$ higher heat transfer. The heat transfer to the coolant in the current case falls well within this range (7-10\%). The influence of engine geometry on heat loss could be more in gas mode compared to diesel because of basic difference in the nature of combustion. In the case of compression ignition engine, combustion is heterogeneous and essentially occurs at multiple ignition sites in a diffusion mode. Therefore, there is no definite flame front propagation and combustion does not occur close to the wall unlike that in a Sparkignition engine. This is one of the prime reasons for increased heat loss to the coolant in spark-ignition engine, which is so in the current study in gas mode. This increased heat loss to the coolant in the gas mode was leading to overheating of the engine within about 30 minutes of operation, this was overcome subsequently by increasing the cooling fan capacity by about $0.5 \mathrm{~kW}$ (incremental power measured by external motoring), whereby the net peak output reduced by the same value. 


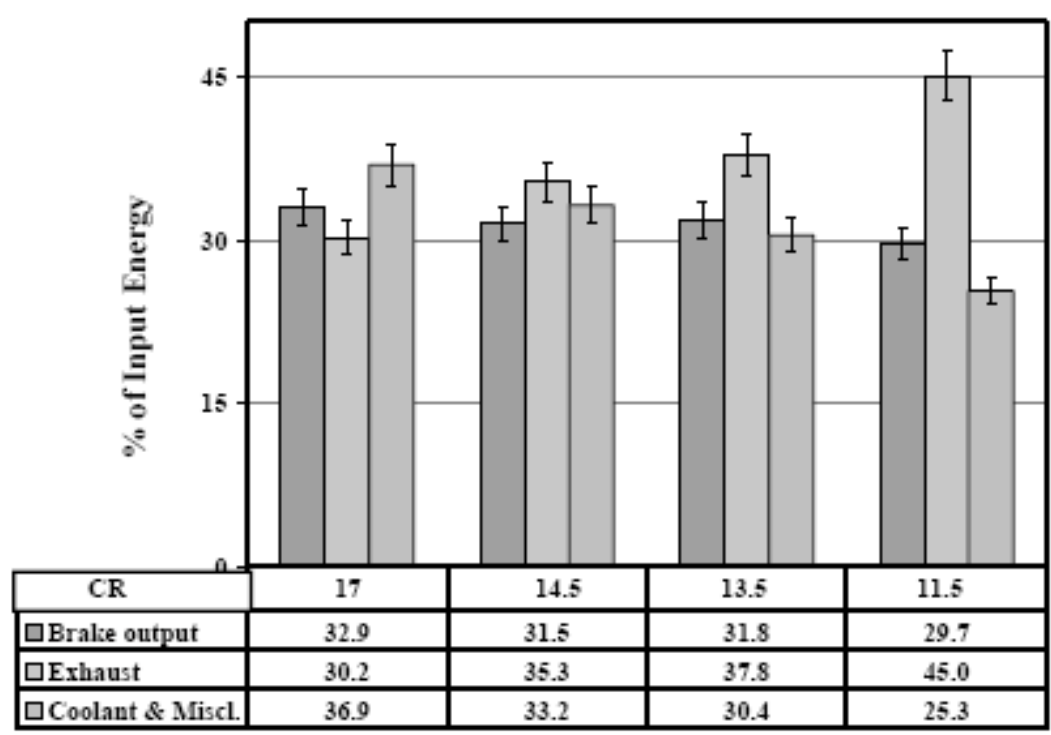

Fig. 8 Comparison of Energy Balance for engine E1 at Various CRs with Producer Gas Corresponding to Maximum Brake Output. The Marker Refers to the Error Band.

The energy balance of engine E2 and E3 at respective MBT was more or less alike. The engine E2 showed $30.2 \%$ realized as useful output, $28 \%$ and $42 \%$ loss to exhaust and coolant respectively. Moreover, there was no problem of coolant water getting overheated because the basic cooling system adopted on these engines are identical to that diesel engine frame (at the same swept volume) and therefore designed to handle larger thermal dissipation.

\subsection{Emissions}

The emissions with producer gas operation on engine E1 and E2 are compared against existing emission standards of various countries in Table 6. The standard given for Indian conditions correspond to that of diesel powered vehicle (Euro l) for gross vehicle weight $>3.5$ tons [http://terin.org/urban/standard.htm]. As stated earlier there are no standards existing for stationary engine $(<2 \mathrm{MW})$, a suggestion made by Indian diesel engine manufacturers association [http://www.kirloskar.com/html/sw/emissions] is pending for approval with CPCB. These are in the brackets in Table 6 under India column. The emissions with producer gas operation correspond to that measured under steady state conditions, using pre-calibrated instruments. However, the standards of various countries correspond to a specific procedure (steady state test cycle) meant for commercial engines. Therefore, the exact procedure might not have been followed in the current study, but measurements were made under steady-state conditions. 
Table 6: Comparison of Emissions (g/MJ) with Producer Gas Operation against Existing Emission Norms in Various Countries

\begin{tabular}{|l|l|l|l|l|}
\hline Parameter/Country* & USA & EU & Japan & India \\
\hline CO & 3.06 & $1.4-1.8$ & 1.67 & $1.25(3.9)$ \\
\hline NOx & 2.56 & 2.56 & $2.6-3.06$ & $2.22(5.0)$ \\
\hline HC & 0.36 & 0.36 & $0.4-0.56$ & $0.3(0.98)$ \\
\hline PM & 0.15 & $0.15-0.24$ & - & $\begin{array}{l}0.1-0.2 \\
(<3.5 \\
\text { Bosch) }\end{array}$ \\
\hline Engine E1 results between 6 to $20^{\circ}$ CA for all CRs (min \& max values) at $\Phi=1.0-1.2$ \\
\hline Parameter/CR & 17.0 & 14.5 & 13.5 & 11.5 \\
\hline CO & $1.1-11.0$ & $11.0-15.0$ & $4.0-16.0$ & $9.0-14.0$ \\
\hline NOx & $0.03-0.28$ & $0.02-0.22$ & $0.03-0.20$ & 0.05 \\
\hline PM & $<0.014$ & & \\
\hline Engine E2 results between 12 to $24^{\circ}$ CA for CR=12.0 at $\Phi=0.94-0.97$ \\
\hline CO & $0.58-1.2$ \\
\hline NOx & $0.32-0.7$ \\
\hline PM & $<0.0005$ \\
\hline Engine E3 results between 22 to $24^{\circ}$ CA for CR=10.0 at $\Phi=1.01-1.03$ \\
\hline CO & $0.4-1.8$ \\
\hline NOx & $0.2-0.7$ \\
\hline PM & $<<0.0005$ \\
\hline
\end{tabular}

Source: http://app10.internet.gov./scripts/nea/cms/htdocs/article.asp, PM is Particulate Matter; this excludes engine oil, which is typically in the range of $0.003-0.1 \mathrm{~g} / \mathrm{MJ}$ [20] in large diesel engines.

It can be seen that NO emission with producer gas is lower than all the existing norms. The prime reason for this to be lower is due to lower peak cylinder temperatures and also lower residence time in the combustion chamber as the MBT is located close to TC. The CO results with engine E2 are encouraging; however there are large deviations with respect to E1 results. Therefore, treatment of exhaust in terms of $\mathrm{CO}$ is mandatory from the viewpoint of deriving maximum output $(\Phi>1.0)$. This could be true even with respect to $\mathrm{HC}$ emissions. However, Particular Matter (PM) is expected to be low even though measurements were not done because the input feed is gas with particulate matter less than $2 \mathrm{mg} / \mathrm{Nm}_{3}$ (with E2 experiments), which amounts to $<0.5 \mathrm{mg} / \mathrm{MJ}$. In the case of E1 experiments $\mathrm{PM}$ is estimated to be less than $14 \mathrm{mg} / \mathrm{MJ}$, with input gas containing particulate matter to the extent of 60 $\mathrm{mg} / \mathrm{Nm}_{3}$. In the case of engine $\mathrm{E} 3$, the particulate content should be much lower as the input feed was measured to contain particulate matter of the order of $0.02 \mathrm{mg} / \mathrm{Nm}_{3}$. The emission recorded on engine E3 during the 24 hour long duration operation is shown in Fig. 9, at a constant load of $52-54 \mathrm{kWe}$. During the initial few hours of operation CO was found to be higher and is related to the tuning of the carburetor in arriving at the correct air-to-fuel ratio. But subsequently the values are much lower than most of the existing emission norms, which implies environmental friendly operation with producer gas fuel. 


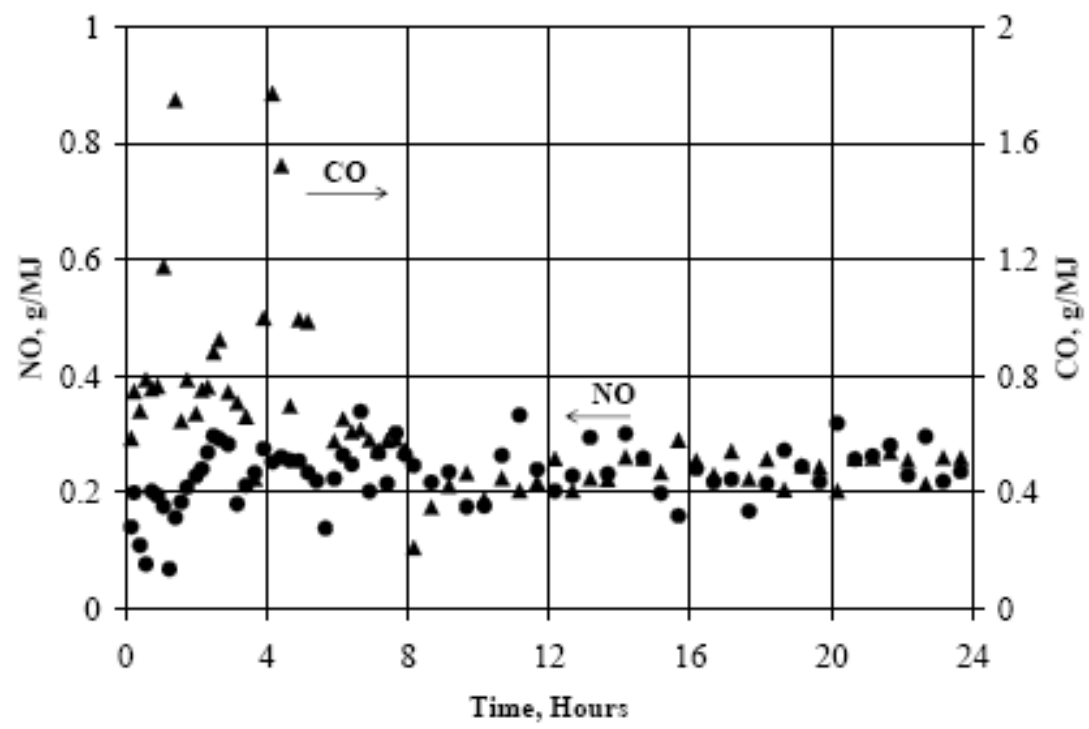

Fig. 9 Variation of emission in the case of engine E3 at $90 \%$ load during 24 hours of continuous operation.

\subsection{Observations}

Summarizing the overall development effort, performance of the engine at higher CR is smooth and it has been established that operating engines using producer gas in SI mode at CR up to 17 is feasible. This is obvious from the $p-\theta$ curve, which shows smooth rise in pressure without any pressure oscillations. A shorter duration of combustion has been observed with producer gas fuel, requiring retardation of the ignition timing to achieve MBT. These faster burning cycles are corroborated by low cyclic pressure fluctuations with coefficient of variation 3\%. The faster burning process has been identified to be due to higher flame speed of the fuel - air mixture and this is attributed to the hydrogen content in the gas. The MBT arrived from this study is much retarded than stated by the earlier researchers. The MBT in the current case are in the range between 6 and $22^{\circ} \mathrm{CA}$ for CR range between 17 and 10 against $30-45^{\circ} \mathrm{CA}$ (for a CR of 11.5 and below) stated by the earlier researchers. This change in ignition advance in the present study can only be attributed to the improved producer gas composition. The hydrogen content in the present case is about $18-20 \%$ against $11-12 \%$ stated by Parke et al $[7,8]$ and $10 \%$ (theoretical) by Martin et al [5]. However, it is difficult to comment on the retarded MBT of $35^{\circ}$ CA stated by Shashikanta et al [10] with hydrogen content of $24 \%$. Also, the MBT with producer gas is much retarded when compared to engines fuelled with NG; this is evident from the results on engine E2 and E3, which is due to higher laminar flame speed with producer gas.

The de-rating in the power output with producer gas fuel for the three engines is summarized in Table 7. This derating is due to the resultant effect of reduction in the mixture energy density and the product-to-reactant mole ratio as discussed in Table 1 . In the case of engine E1 at a $C R=17$, the derating is about $16.7 \%$ and increases to about $19 \%$ in the event of enhancing the engine cooling system for practical field operations. The extent of de-rating is much lower when compared to any of the previous studies [5, 7, 8 and 12]. This value at $C R=17$ matches with a similar kind of de-rating reported with natural gas operation by Das et al [15]. In the case of engine E2, the derating is about $30 \%$ compared to operations on identical engine using diluted natural gas. The data with diluted natural gas (biogas) has been recorded on a field system comprising of a Greaves engine (identical to E2) at UGAR Sugars Ltd, Belgaum, Karnataka, India. This de-rating appears to be higher when compared to the results of engine E1 (26\% at CR=11.5). However, as indicated in Table 5 , the mixture density in the experiments on engine E2 was about $1.9 \mathrm{MJ} / \mathrm{kg}$, which is about $10 \%$ lower than what has been measured on similar class gasifier. If an increment of $10 \%$ in the mixture density is considered (which is 
actually so with respect to the tests on $\mathrm{E} 1$ - Table-2) the de-rating is reduced to about $22 \%$ at the expected output of $202 \mathrm{~kW}$ with producer gas (LCV 4.8 MJ/kg). In the case of engine E3, the derating is to the extent of $28.5 \%$, with the basic rating of the engine at $84 \mathrm{~kW}$ on pure NG. In reality, it is possible that the difference in derating for engines E2 and E3 to be marginal, if true rating for the engines is considered using NG. This loss in power to some extent can be lowered by working at higher CR in the case of naturally aspirated engine and by addressing issues related to compressor-turbine matching in the case of a turbocharged engine. For instance, the incremental gain in power per unit CR is about 2.2 to $2.5 \%$ [18, 20], therefore adapting a $C R=15-17$ as against $C R=10$ implies higher output by 13 to $18 \%$.

The emission in terms of $\mathrm{NO}$ is found to be much lower than the stipulated emission norms of CPCB and Swiss. However, the CO levels are found to be higher in the case of engine E1, but meet the emission norms in the case of engine E2 by using the indigenously built producer gas carburetor. These observations are consistent with the results of Giordano [24] on a producer gas engine powered with an IISC gasifier. Lastly, the information that is relevant to biomass gasifier coupled to a gas engine is the specific fuel (biomass) consumption. The specific biomass works out to about 1.00-1.20 kg per kWh electric energy generated that corresponds to an overall efficiency (biomass to electricity) of 24 to $20 \%$. Currently the tested systems are being monitored as field installations at industrial establishments.

Table 7: Summary of Producer Gas Engines

\begin{tabular}{|c|c|c|c|c|c|}
\hline Engine & CR & $\begin{array}{l}\text { Net Rating, } \\
\text { kW }\end{array}$ & $\begin{array}{l}\text { Achieved } \\
\text { Output, kW }\end{array}$ & Derating, \% & Remarks \\
\hline E1 & \multirow[b]{2}{*}{17.0} & \multirow[b]{2}{*}{24} & 20 & 16.7 & \\
\hline E1 & & & 19.5 & 19.0 & $\begin{array}{l}\text { Increased } \\
\text { cooling } \\
\text { capacity }\end{array}$ \\
\hline E2 & 12.0 & \multirow{2}{*}{$\begin{array}{c}258 \text { on } \\
\text { diluted } \\
\text { natural gas } \\
(75 \% \mathrm{CH} 4)\end{array}$} & 182 & 30.0 & \\
\hline E2 & 12.0 & & 202 & 22.0 & $\begin{array}{c}\text { with } 10 \% \\
\text { increase in } \\
\text { LCV }\end{array}$ \\
\hline E3 & 10.0 & 84 & 60 & 28.5 & \\
\hline
\end{tabular}

Based on the above study, a short range of optimum ignition timing is identified as shown in Table 8 for producer gas fuel. This could nevertheless vary depending upon the actual fuel-gas composition, combustion chamber design and engine speed. However, these data can be used as initial indicators and further tuned for best performance based on actual engine configuration and fuel-gas composition.

Table 8: Optimum Ignition Timing (MBT) at Varying CR

\begin{tabular}{|c|c|}
\hline $\begin{array}{c}\text { Range } \\
\text { In CR }\end{array}$ & $\begin{array}{c}\text { Ignition Timing, } \\
{ }^{\circ} \text { BTC }\end{array}$ \\
\hline 17 & $6-10$ \\
\hline $14-15$ & $10-12$ \\
\hline $12-13$ & $12-14$ \\
\hline $11-12$ & $15-17$ \\
\hline $10-11$ & $22-24$ \\
\hline $8-9$ & $26-28$ \\
\hline
\end{tabular}




\subsection{Conclusion}

The developmental studies on producer gas engine reveal that smooth operation is possible right from the highest CR of 17, with varying de-rating identified at lower CR. It is shown from the above sets of trails that it is possible to operate commercially available gas engines (meant for natural gas etc) on low energy density producer gas by employing suitably designed gas carburetor. This study therefore paves path for the possibility of adapting commercially available gas engine for large scale power generation application, albeit loss of power to an extent of $20-30 \%$. This loss in power is compensated to a much larger proportion as these technologies generate fewer amounts of toxic gases (low NOx and almost zero SOx) and zero towards Green House Gas emissions.

\section{Acknowledgement}

The authors express their gratitude to Ministry of Non conventional Energy Sources, Govt. of India, under whose auspices this development work was conducted. Similarly, the authors express their thanks to Greaves Ltd, Pune and Cummins India, Pune for their cooperation extended in this developmental activity.

\section{References}

1. Mukunda H.S., Dasappa S. and Shrinivasa U. Open-Top Wood Gasifiers, Renewable Energy Sources for Fuels and Electricity, Island press, 1993, pp. 699-728.

2. SERI, Generator Gas - The Swedish Experience From 1939-1945, SERI, 1979, Golden, Colorado.

3. Mukunda H.S., Paul P.J., Dasappa S., Shrinivasa U. and Sharan H. Results of an Indo-Swiss Programme For Qualification and Testing of a 300-kW IISc-Dasag Gasifier, Energy for sustainable development, 1994, Vol. 4, pp.46-49.

4. Anon, Wood gas as engine fuel, A Report of the Mechanical Wood Products Branch of FAO Forestry, Food and Agriculture Organization of United Nations, Rome, Paper No. 72, 1986.

5. Martin J. and Wauters P. Performance of Charcoal Gas Internal Combustion Engines, Proceedings of International Conference - New Energy Conversion Technologies and Their Commercialization, 1981, Vol. 2, pp. 1415-1424.

6. Tatom J. W., Colcord A.R., Williams W.M., Purdy K.R. and Beinstock D. Development of a Prototype System for Pyrolysis of Agricultural and Forestry Wastes into Fuels and Other Products, 1976, Prepared for EPA.

7. Parke P.P., Stanley S.J. and Walawnder W. Biomass Producer Gas Fuelling of Internal Combustion Engines, Energy From Biomass and Wastes V, Lake Buena Vista Florida, 1981, pp. $499-516$.

8. Parke P.P. and Clark, S.J. Biomass Producer Gas Fuelling of IC Engines -Naturally Aspirated and Supercharged Engines, American Society of AgriculturalEngineers, Michigan, 1981, pp. 135.

9. Shashikantha, Banerjee P.K., Khairnar G.S., Kamat P.P. and Parikh P.P. Development and Performance Analysis of a $15 \mathrm{kWe}$ Producer Gas Operated SI Engine, Proceedings of Fourth National Meet on Biomass Gasification and Combustion, Mysore, India, 1993, Vol. 4, pp. 219 231. 
10. Shashikantha and Parikh P.P. Spark Ignited Producer gas and Dedicated CNG Engine Technology Development and Experimental Performance, SAE 1999-01-3515 (SP-1482), 1999.

11. Parikh P.P., Banerjee P.K., Shashikantha and Veerkar S. Design Development and Optimisation of a Spark Ignited Producer Gas Engine, Proceedings of XIV National Conference on IC engines and Combustion, Pune, India, 1995, Vol. 14, pp. 97-107.

12. Ramachandra A. Performance Studies on a Wood Gas Run IC engine, Proceedings of Fourth National Meet on Biomass Gasification and Combustion, Mysore, India, 1993, Vol. 4, pp. 213218.

13. Kanitkar S., Chakravarty P., Paul P.J. and Mukunda H.S. The Flame Speeds, Temperature and Limits of Flame Propagation for Producer Gas-Air Mixtures -Experimental Results, Proceedings of Fourth National Meet on Biomass Gasificationand Combustion, Mysore, India, 1993, Vol. 4, pp. 50-62.

14. Fleischer F., Grosse W. and Zapf H. Fuels From Biomass and Their Rational Utilisation in Internal Combustion Engines, Proceedings International Conference -New Energy Conversion Technologies and Their Commercializations, 1981, Vol. 2, pp.1334-1340.

15. Das A. and Watson H.C. Development of a Natural Gas Spark Ignition Engine for Optimum Performance, Proceedings Institution of Mechanical Engineers, Part D, 1997, Vol. 211, pp. 361378.

16. Lewis B. and Elbe G Von. Combustion, Flames and Explosion of Gases, Academic Press Inc, 1987.

17. Mukunda H.S. Understanding Combustion, Macmillan India Limited, 1989.

18. Sridhar, G., Paul, P.J., Mukunda, H.S., Biomass derived producer gas as a reciprocating engine fuel - an experimental analysis, Biomass \& Bioenergy, 21, 61-72, 2001.

19. Sridhar, G. Experimental and Modelling studies of producer gas based sparkignited reciprocating engines - Ph.D. thesis, Indian Institute of Science, 2003.

20. Heywood J.B. Internal Combustion Engine Fundamentals, International edition. McGrawHill, 1988.

21. Wu C.M., Roberts C.E., Matthews R.D. and Hall M.J. Effects of Engine Speed on Combustion in SI Engines: Comparison of Predictions of a Fractal Burning Model with Experimental Data, SAE 932714, Vol. 102, pp. 2277-2291, 1993.

22. Sridhar, G., Paul, P.J., Mukunda, H.S. Experiments and Modeling of Producer Gas Based Reciprocating Engines, Proceedings of the 2002 Fall Technical Conference of The ASME Internal Combustion Engines Division, held at New Orleans, Louisiana, USA, , ICE-Vol. 39, Paper No. ICEF2002-520, pp. 377-388, 2002.

23. Cummins Gas Engines Service Manual, Cummins India Ltd.

24. Giordano P. Experience on Running a Wood Based Co-generation Power Plant with The IISCDasag Gasifier, Biomass Users Network (BUN-India), Vol. 3.2, p. 2,1999. 


\section{List of Tables}

1. Properties of Producer Gas (PG) Compared with Pure Combustible Gases

2. Engine Specifications

3. MBT Identification - Cylinder Peak Pressures and Their Occurrence

4. Maximum Net Engine Output on Engine E1 as a Function of Ignition Timing and CR

5. Maximum Net Engine Output on different engines

6. Comparison of Emissions (g/MJ) with Producer Gas Operation against Existing Emission Norms in Various Countries

7. Summary of Producer Gas Engines

8. Optimum Ignition Timing at Varying $C R$

\section{List of Illustrations}

1. Schematic of Producer Gas Carburetor with Zero Pressure Regulator in the Gas-Air Line Circuit

2. Flow Tests with Gas Carburetor at Varying Area Ratio for Air and Fuel Entry

3. Schematic of Open Top Re-burn Gasifier Connected to gas engine

4. Comparison of p- $\theta$ Curves at Different CR; Ignition Timing is at MBT or Close to MBT (Within $\left.\mathrm{MBT}+2^{\circ} \mathrm{CA}\right)$. The $\mathrm{p}-\theta$ curves correspond to ignition setting of $10^{\circ}, 10^{\circ}, 14^{\circ}$ and $15^{\circ} \mathrm{BTC}$ for CR of 17, 14.5, 13.5 and 11.5 respectively. Operation in Diesel Mode at $90 \%$ of rated Load (at Optimum Injection Timing - $34^{\circ}$ BTC). All are Ensemble-Averaged Data Over 30 Consecutive Cycles. The net brake power and $\Phi$ for these cycles are shown in Table 5.

6. p- $\theta$ recording at Varying Ignition Advance at $80 \%$ of the achieved maximum output with Producer Gas. Ensemble- Averaged Data Over 30 Consecutive

Cycles

7. Variation of IMEP (Net) for engine E1 with Ignition Advance at Various CRs 8. Energy Balance Comparison for engine E1 in Diesel and Producer Gas Mode at Maximum Brake Output. The Marker Refers to the Error Band.

Comparison of Energy Balance for engine E1 at Various CRs with Producer Gas Corresponding to Maximum Brake Output. The Marker Refers to the Error Band. 10. Variation of emission in the case of engine E3 at $90 \%$ load during 24 hours of continuous operation 